ISSN: $2339-2479$

\title{
Ketahanan Galur Padi Hibrida Potensi Hasil Tinggi terhadap Penyakit Tungro
}

\section{Resistance of Rice Hybride Lines with High Yield Potential to Tungro Disease}

\author{
Ifa Manzila*, Tri Puji Priyatno, Ida Hanarida \\ Balai Penelitian dan Pengembangan Bioteknologi dan Sumberdaya Genetik Pertanian, Bogor 16111
}

\begin{abstract}
ABSTRAK
Aksesi padi liar Oryza rufipogon dapat mejadi sumber gen sumber ketahanan padi varietas elit tahan virus tungro. Penelitian ini bertujuan menguji beberapa galur padi potensi hasil tinggi dari induk persilangan IR64 dengan O. rufipogon terhadap tiga isolat virus tungro yang berasal dari Bogor, Sumedang, dan Bali. Pengujian dilakukan dengan penularan virus menggunakan serangga vektornya wereng hijau, Nephottetix virescens. Hasil penelitian menunjukkan variasi respons ketahanan. Tiga galur padi, Bio5-AC-Blas/BLB, Bio62-AC-Blas/BLB-03, Bio111-BC-Pir7, memberikan respons resisten yang stabil terhadap semua isolat virus tungro; 6 galur, Bio132-AC2-Blas, Bio138-AC2-Blas, Bio148Mamol-Dro, Bio154-Mamol-Dro, Bio159-Mamol-Dro, Bio 153-Mamol-Dro, bersifat moderat resisten. Isolat virus tungro asal Sumedang dan Bali memiliki virulensi lebih tinggi dibandingkan dengan isolat Bogor berdasarkan pengamatan masa inkubasi, tingkat keparahan penyakit dan penghambatan terhadap tinggi tanaman.
\end{abstract}

Kata Kunci: indeks penyakit, Oryza rufipogon, virulensi, wereng hijau

\begin{abstract}
Wild rice Oryza rufipogon accession can be used as a source of resistance genes to develop elite rice varieties for Rice tungro virus. This study aimed to examine some potential high yield rice lines developed by crossing IR64 with O. rufipogon for their response to three isolates of Rice tungro virus originating from Bogor, Sumedang, and Bali. Virus transmission was done by insect vector, Nephottetix virescens. Variation on plant response was observed. Three lines i.e. Bio5-AC-Blas/BLB, Bio62-ACBlas/BLB-03, Bio111-BC-Pir7, showed stabile resistance response to all isolates of Rice tungro virus; 6 lines i.e. Bio132-AC2-Blas, Bio138-AC2-Blas, Bio148-Mamol-Dro, Bio154-Mamol-Dro, Bio159Mamol-Dro, Bio 153-Mamol-Dro were moderately resistance. Virus isolates from Sumedang and Bali is more virulence than isolate from Bogor based on observation on incubation period, disease severity and suppression of plant height.
\end{abstract}

Key words: disease index, green planthopper, Oryza rufipogon, virulence

*Alamat penulis korespondensi: Balai Penelitian dan Pengembangan Bioteknologi dan Sumberdaya Genetik Pertanian Jalan Tentara Pelajar 3A, Bogor 16111.

Tel: 0251-8345975, Faks: 0251-8338820,Surel: ifamanzila@gmail.com 


\section{PENDAHULUAN}

Penyakit tungro merupakan penyakit penting ketiga pada tanaman padi setelah penyakit hawar daun bakteri (HDB) dan blas. Penyakit tungro disebabkan oleh infeksi dua jenis virus, yaitu Rice tungro bacilliform virus (RTBV) dan Rice tungro sphaerical virus (RTSV), serta ditularkan oleh serangga vektor wereng hijau, Nephottetix virescens. Rice tungro bacilliform virus (RTBV) adalah anggota famili Caulimoviridae dengan genom berupa dsDNA, sedangkan RTSV termasuk dalam famili Sequiviridae dengan genom berupa ssRNA (Hull et al. 2000). Penyebaran RTBV dari satu tanaman ke tanaman lainnya oleh $N$. virescens sangat bergantung pada RTSV yang berperan sebagai virus pembantu (helper virus) (Chancellor et al. 1999). Insidensi penyakit yang meluas jarang terjadi secara nasional, tetapi insidensi penyakit secara sporadik di kawasan-kawasan endemik selalu terjadi pada kondisi lingkungan mendukung. Kehilangan hasil akibat penyakit tungro mencapai rata-rata US \$ 343 juta tiap tahunnya di kawasan Asia Tenggarra (Neeraja et al. 2010).

Tingkat kerusakan yang disebabkan penyakit tungro sangat bergantung pada jenis varietas padi, galur virus, umur tanaman, infeksi tunggal atau ganda, dan lingkungan (Chancellor et al. 1999). Infeksi virus tungro pada tanaman tahan biasanya tidak menimbulkan gejala atau gejala muncul lambat yang akan hilang ketika tanaman sudah dewasa. Infeksi tunggal RTBV dapat menimbulkan gejala tungro, sedangkan infeksi tunggal RTSV biasanya tidak menampakkan gejala, tetapi gejala terlihat lebih parah apabila tanaman terinfeksi ganda RTBV dan RTSV. Tanaman yang terinfeksi ganda akan menunjukkan gejala daun menjadi berwarna kuning hingga kuning-oranye serta tampak ada bintik-bintik karat pada permukaan daunnya. Jumlah anakan tanaman juga mengalami penurunan.

Sudah banyak sumber ketahanan terhadap vektor dan RTSV yang telah diidentifikasi pada plasma nutfah yang ada, tetapi gen ketahanan terhadap RTBV masih sangat sedikit yang diketahui. Uthri Rajapan, Balimau Putih, Pankhari 203 dan Tiloekkachari merupakan varietas padi yang sangat rentan terhadap RTBV saja atau RTBV bersama RTSV, meski dengan tingkat keparahan gejala yang rendah (Chancellor et al. 1999). Pembentukan varietas tahan tungro yang bersifat durable resistance dengan pendekatan gene pyramiding menjadi salah satu pilihan untuk mengatasi perubahan keragaman genetik patogen tungro. Pemuliaan konvensional yang didukung dengan teknologi marka molekuler (marker assisted selection) adalah salah satu pendekatan yang dapat ditempuh dalam pembentukan varietas tahan tungro. Permasalahannya, sampai saat ini variasi dan pola pergeseran galur tungro di Indonesia, khususnya Jawa dan Bali, belum terpetakan sehingga arah pengembangan varietas tahan yang bersifat durable resistance terhadap tungro sukar dilakukan.

Penelitian dilakukan untuk menentukan respons ketahanan 16 galur padi hasil pemuliaan BB Biogen yang memiliki potensi berdaya hasil tinggi terhadap isolat tungro yang berasal dari tiga daerah endemik penyakit tungro, yaitu Sumedang, Bogor, dan Bali.

\section{BAHAN DAN METODE}

\section{Galur Padi dan Virus Tungro}

Evaluasi galur padi dilakukan di Laboratorium Virologi dan Rumah Kasa BB Biogen. Bahan tanaman yang digunakan adalah 16 galur padi hibrida koleksi BB Biogen (Tabel 1). Isolat virus tungro yang digunakan berasal dari Cipeles-Tomo (Sumedang), Cinangneng (Bogor), dan Gianyar (Bali).

\section{Perbanyakan Sumber Inokulum Virus}

Perbanyakan sumber inokulum virus dilakukan melalui penularan dengan serangga vektor wereng hijau $N$. virescens. Sejumlah wereng hijau diinfestasikan ke tanaman sakit selama 24 jam. Setelah periode akuisisi terpenuhi serangga vektor wereng hijau dipindahkan ke tanaman padi sehat, yaitu varietas TN1 selama 24 jam. Tanaman yang terinfeksi akan digunakan sebagai tanaman 
sumber inokulum untuk kegiatan penelitian selanjutnya.

\section{Evaluasi Ketahanan 16 Galur Padi Hibrida}

Evaluasi ketahanan sejumlah galur padi hibrida terhadap penyakit tungro dilakukan di rumah kasa. Kegiatan yang dilakukan meliputi 3 tahapan: periode makan akuisisi, periode makan inokulasi, pengamatan respons tanaman uji terhadap penyakit tungro. Galurgalur uji ditanam mengikuti pedoman pengujian international rice testing nursery (IRTN). Setiap galur yang diuji ditanam dalam dua baris. Setiap baris terdiri atas 10 bibit, kemudian di antaranya ditanam padi varietas TN1 sebagai pembanding rentan dan Utri Merah dan Utri Rajapan sebagai pembanding tahan.

Periode makan akuisisi dilakukan dengan menginfestasikan beberapa serangga vektor wereng hijau pada tanaman sumber inokulum virus tungro selama 24 jam. Setelah melalui

Tabel 1 Galur padi hamparan yang digunakan untuk pengujian ketahanan terhadap penyakit tungro

\begin{tabular}{lc}
\hline Galur harapan/Varietas & Asal benih \\
\hline Bio5-AC-Blas/BLB & BB Biogen \\
Bio62-AC-Blas/BLB-03 & BB Biogen \\
Bio111-BC-Pir7 & BB Biogen \\
Bio127-BC-WBC & BB Biogen \\
Bio129-BC-WBC & BB Biogen \\
Bio132-AC2-Blas & BB Biogen \\
Bio138-AC2-Blas & BB Biogen \\
Bio140-AC2-Blas & BB Biogen \\
Bio148-Mamol-Dro & BB Biogen \\
Bio154-Mamol-Dro & BB Biogen \\
Bio155-Mamol-Dro & BB Biogen \\
Bio157-Mamol-Dro & BB Biogen \\
Bio159-Mamol-Dro & BB Biogen \\
Bio 153-Mamol-Dro & BB Biogen \\
'Ciherang' & BB Padi \\
'INPARI 1' & BB Padi \\
'Pelita' & BB Padi \\
'Utri Rajapan' & BB Padi \\
'Utri Merah' & BB Padi \\
\hline
\end{tabular}

BB Biogen, Balai Besar Penelitian dan Pengembangan Bioteknologi dan Sumberdaya Genetik Pertanian; BB Padi, Balai Besar Penelitian Padi. periode makan akuisisi, serangga vektor wereng hijau dipindahkan ke tanaman uji (16 galur padi hibrida), sebanyak 2 ekor serangga per tanaman, untuk diberikan periode makan inokulasi selama24jam. Pengamatan dilakukan dua kali, yaitu pada 15 dan 30 hari setelah inokulasi (HSI) terhadap penghambatan tinggi tanaman, insidensi penyakit dan keparahan penyakit. Persentase penghambatan tinggi tanaman dihitung berdasarkan proporsi selisih tinggi tanaman kontrol dan tanaman uji dengan tinggi tanaman kontrol. Pengamatan kejadian penyakit tungro dilakukan pada semua rumpun tanaman, sedangkan tingkat keparahan penyakit dievaluasi menggunakan standard evaluation system for rice (SESR) (IRRI 1996) dengan skor (Tabel 2)

Berdasarkan skala keparahan penyakit tersebut kemudian dihitung indeks penyakit tungro dengan rumus sebagai berikut:

$D I=\frac{n(1)+n(3)+n(5)+n(7)+n(9)}{t n}$, dengan

DI, indeks penyakit; $n$, jumlah tanaman yang menunjukkan nilai skor tertentu; tn, total tanaman yang diamati.

Tingkat keparahan gejala tungro ditentukan berdasarkan nilai DI, yang berarti bahwa semakin tinggi nilai DI maka gejala yang ditimbulkan semakin parah dan sebaliknya.

Tabel 2 Skala keparahan penyakit tungro (IRRI 1996)

\begin{tabular}{cl} 
Skor & \multicolumn{1}{c}{ Deskripsi gejala } \\
\hline 1 & Tidak ada gejala \\
3 & $\begin{array}{l}\text { Penghambatan tinggi tanaman } 1-10 \%, \\
\text { perubahan warna daun dari kuning ke } \\
\text { kuning oranye tidak nyata }\end{array}$ \\
5 & $\begin{array}{l}\text { Penghambatan tinggi tanaman 11- } \\
\text { 30\%, perubahan warna daun dari ku- } \\
\text { ning ke kuning oranye tidak nyata } \\
7\end{array}$ \\
& $\begin{array}{l}\text { Penghambatan tinggi tanaman } 31- \\
\text { 50\%, perubahan warna daun dari ku- } \\
\text { ning ke kuning oranye nyata }\end{array}$ \\
& $\begin{array}{l}\text { Penghambatan tinggi tanaman }>50 \%, \\
\text { perubahan warna daun dari kuning ke } \\
\text { kuning oranye nyata }\end{array}$ \\
&
\end{tabular}




\section{HASIL}

Respons 16 galur uji terhadap tiga isolat virus tungro menunjukkan keragaman dengan respons tanaman tergolong resisten, moderat resisten, dan suseptibel. Kelompok galur resisten $(\mathrm{R})$ dengan kejadian penyakit 11.1-17\%, skala keparahan 1.1-2.4 dan penghambatan tinggi tanaman berkisar antara 6.7-16.8\%, terdiri atas galur Bio5-AC-Blas/BLB, Bio62-AC-Blas/BLB03, Bio111-BC-Pir7. Tingkat ketahanan ketiga galur tersebut setara dengan Utri Merah dan Utri Rajapan sebagai pembanding varietas tahan. Kelompok galur dengan respons moderat resisten (MR) atau agak tahan dengan kejadian penyakit berkisar antara $25.5 \%$ dan $35.5 \%$, skala keparahan mencapai 2.6-4.2 dan penghambatan tinggi tanaman berkisar antara $23.3 \%$ dan $36.30 \%$ yang terdiri atas 6 galur, yaitu Bio132-AC2-Blas, Bio138-AC2Blas, Bio148-Mamol-Dro, Bio154-Mamol-
Dro, Bio159-Mamol-Dro, Bio 153-MamolDro. Kelompok dengan respons suseptibel (S) terdiri atas 5 galur, yaitu Bio127-BCWBC, Bio129-BC-WBC, Bio140-AC2-Blas, Bio155-Mamol-Dro, Bio157-Mamol-Dro dengan kejadian penyakit 46.7-95.6\%, skala keparahan 4.6- 8.6 dan tingkat penghambatan tinggi tanaman mencapai 40-55\% (Tabel 3, 4, 5).

Infeksi virus tungro pada bibit padi ditunjukkan oleh gejala kerdil karena ada pemendekan pelepah dan helai daun, selain gejala khas klorosis (Gambar 1). Terhambatnya pertumbuhan pelepah daun menyebabkan daun muda yang seharusnya membentang tertahan oleh pelepah daun bagian luar. Tingkat penghambatan tinggi tanaman bervariasi bergantung pada galur/ varietas dan tingkat virulensi isolat virus tungro. Gejala kekerdilan semakin berkurang dengan meningkatnya umur tanaman sewaktu terinfeksi.

Tabel 3 Respons beberapa galur/varietas padi terhadap infeksi tiga isolat virus tungro berdasarkan pengukuran kejadian penyakit pada 15 dan 30 hari setelah inokulasi (HSI)

\begin{tabular}{|c|c|c|c|c|c|c|c|}
\hline \multirow{3}{*}{ Galur/Varietas } & \multicolumn{6}{|c|}{ Isolat virus tungro } & \multirow{3}{*}{ Respons } \\
\hline & \multicolumn{2}{|c|}{ Sumedang } & \multicolumn{2}{|c|}{ Bogor } & \multicolumn{2}{|c|}{ Bali } & \\
\hline & $15 \mathrm{HSI}$ & $30 \mathrm{HSI}$ & $15 \mathrm{HSI}$ & $30 \mathrm{HSI}$ & $15 \mathrm{HSI}$ & 30 HSI & \\
\hline Bio5-AC-Blas/BLB & 11.1 & 11.1 & 11.11 & 8.89 & 17.8 & 28.9 & $\mathrm{R}$ \\
\hline Bio62-AC-Blas/BLB-03 & 11.1 & 11.1 & 11.11 & 10.00 & 22.2 & 28.9 & $\mathrm{R}$ \\
\hline Bio111-BC-Pir7 & 11.1 & 11.1 & 15.56 & 17.78 & 17.8 & 13.3 & $\mathrm{R}$ \\
\hline Bio127-BC-WBC & 68.9 & 64.4 & 43.33 & 78.89 & 75.6 & 80.0 & $\mathrm{~S}$ \\
\hline Bio129-BC-WBC & 60.0 & 51.1 & 52.22 & 51.11 & 62.2 & 68.9 & $\mathrm{~S}$ \\
\hline Bio132-AC2-Blas & 40.0 & 42.2 & 30.00 & 42.22 & 44.4 & 44.4 & MR \\
\hline Bio138-AC2-Blas & 77.8 & 46.7 & 17.78 & 46.67 & 77.8 & 77.8 & MR \\
\hline Bio140-AC2-Blas & 64.4 & 46.7 & 64.44 & 46.67 & 73.3 & 77.8 & $\mathrm{~S}$ \\
\hline Bio148-Mamol-Dro & 28.9 & 98.9 & 7.78 & 44.44 & 46.7 & 57.8 & MR \\
\hline Bio154-Mamol-Dro & 28.9 & 46.7 & 28.89 & 46.67 & 42.2 & 42.2 & MR \\
\hline Bio155-Mamol-Dro & 35.6 & 60.0 & 35.56 & 60.00 & 51.1 & 64.4 & $\mathrm{~S}$ \\
\hline Bio157-Mamol-Dro & 77.8 & 60.0 & 37.78 & 60.00 & 77.8 & 80.0 & $\mathrm{~S}$ \\
\hline Bio159-Mamol-Dro & 31.1 & 51.1 & 25.56 & 60.00 & 40.0 & 51.1 & MR \\
\hline Bio 153-Mamol-Dro & 35.6 & 53.3 & 35.56 & 53.33 & 42.2 & 55.6 & MR \\
\hline Ciherang & 84.4 & 95.6 & 34.44 & 95.56 & 84.4 & 86.7 & $\mathrm{~S}$ \\
\hline INPARI 1 & 42.2 & 60.0 & 42.22 & 60.00 & 55.6 & 62.2 & MR \\
\hline Pelita & 95.6 & 82.2 & 15.56 & 82.22 & 95.6 & 144.4 & $\mathrm{~S}$ \\
\hline Utri Rajapan & 11.1 & 11.1 & 11.11 & 11.11 & 15.6 & 20.0 & $\mathrm{R}$ \\
\hline Utri Merah & 11.1 & 11.1 & 11.11 & 11.11 & 11.1 & 11.1 & $\mathrm{R}$ \\
\hline
\end{tabular}

$\mathrm{R}$, resisten; MR, moderat resisten; $\mathrm{S}$, suseptibel. 
Tabel 4 Respons beberapa galur/varietas padi terhadap infeksi tiga isolat virus tungro berdasarkan pengukuran keparahan penyakit pada 15 dan 30 hari setelah inokulasi (HSI)

\begin{tabular}{|c|c|c|c|c|c|c|c|}
\hline \multirow{3}{*}{ Galur/Varietas } & \multicolumn{6}{|c|}{ Isolat virus tungro } & \multirow{3}{*}{ Respons } \\
\hline & \multicolumn{2}{|c|}{ Sumedang } & \multicolumn{2}{|c|}{ Bogor } & \multicolumn{2}{|c|}{ Bali } & \\
\hline & $15 \mathrm{HSI}$ & $30 \mathrm{HSI}$ & $15 \mathrm{HSI}$ & $30 \mathrm{HSI}$ & $15 \mathrm{HSI}$ & $30 \mathrm{HSI}$ & \\
\hline Bio5-AC-Blas/BLB & 1.1 & 1.1 & 1.1 & 0.8 & 1.6 & 2.6 & $\mathrm{R}$ \\
\hline Bio62-AC-Blas/BLB-03 & 1.1 & 1.1 & 1.1 & 0.9 & 2.0 & 2.6 & $\mathrm{R}$ \\
\hline Bio111-BC-Pir7 & 1.1 & 1.1 & 1.4 & 1.6 & 1.6 & 1.2 & $\mathrm{R}$ \\
\hline Bio127-BC-WBC & 6.2 & 5.8 & 3.9 & 7.1 & 6.8 & 7.2 & $\mathrm{~S}$ \\
\hline Bio129-BC-WBC & 5.4 & 4.6 & 4.7 & 4.6 & 5.6 & 6.2 & $\mathrm{~S}$ \\
\hline Bio132-AC2-Blas & 3.6 & 3.8 & 2.7 & 3.8 & 4.0 & 4.0 & MR \\
\hline Bio138-AC2-Blas & 7.0 & 4.2 & 1.6 & 4.2 & 7.0 & 7.0 & MR \\
\hline Bio140-AC2-Blas & 5.8 & 4.2 & 5.8 & 4.2 & 6.6 & 7.0 & $\mathrm{~S}$ \\
\hline Bio148-Mamol-Dro & 2.6 & 8.9 & 0.7 & 4.0 & 4.2 & 5.2 & MR \\
\hline Bio154-Mamol-Dro & 2.6 & 4.2 & 2.6 & 4.2 & 3.8 & 3.8 & MR \\
\hline Bio155-Mamol-Dro & 3.2 & 5.4 & 3.2 & 5.4 & 4.6 & 5.8 & $\mathrm{~S}$ \\
\hline Bio157-Mamol-Dro & 7.0 & 5.4 & 3.4 & 5.4 & 7.0 & 7.2 & S \\
\hline Bio159-Mamol-Dro & 2.8 & 4.6 & 2.3 & 5.4 & 3.6 & 4.6 & MR \\
\hline Bio 153-Mamol-Dro & 3.2 & 4.8 & 3.2 & 4.8 & 3.8 & 5.0 & MR \\
\hline Ciherang & 7.6 & 8.6 & 3.1 & 8.6 & 7.6 & 7.8 & $\mathrm{~S}$ \\
\hline INPARI 1 & 3.8 & 5.4 & 3.8 & 5.4 & 5.0 & 5.6 & MR \\
\hline Pelita & 8.6 & 7.4 & 1.4 & 7.4 & 8.6 & 8.8 & $\mathrm{~S}$ \\
\hline Utri Rajapan & 1.1 & 1.1 & 1.1 & 1.1 & 1.1 & 1.1 & $\mathrm{R}$ \\
\hline Utri Merah & 1.1 & 1.1 & 1.1 & 1.1 & 1.1 & 1.1 & $\mathrm{R}$ \\
\hline
\end{tabular}

$\mathrm{R}$, resisten; MR, moderat resisten; $\mathrm{S}$, suseptibel.

Tabel 5 Respons beberapa galur/varietas padi terhadap infeksi tiga isolat virus tungro berdasarkan pengukuran penghambatan tinggi tanaman pada 15 dan 30 hari setelah inokulasi (HSI)

\begin{tabular}{|c|c|c|c|c|c|c|c|}
\hline \multirow{3}{*}{ Galur/Varietas } & \multicolumn{6}{|c|}{ Isolat virus tungro } & \multirow{3}{*}{ Respons } \\
\hline & \multicolumn{2}{|c|}{ Sumedang } & \multicolumn{2}{|c|}{ Bogor } & \multicolumn{2}{|c|}{ Bali } & \\
\hline & $15 \mathrm{HSI}$ & $30 \mathrm{HSI}$ & $15 \mathrm{HSI}$ & $30 \mathrm{HSI}$ & $15 \mathrm{HSI}$ & $30 \mathrm{HSI}$ & \\
\hline Bio5-AC-Blas/BLB & 6.7 & 9.7 & 6.7 & 9.8 & 18.9 & 18.9 & $\mathrm{R}$ \\
\hline Bio62-AC-Blas/BLB-03 & 12.8 & 10.2 & 12.6 & 10.2 & 20.0 & 16.8 & $\mathrm{R}$ \\
\hline Bio111-BC-Pir7 & 6.7 & 7.5 & 13.5 & 14.6 & 15.8 & 17.1 & $\mathrm{R}$ \\
\hline Bio127-BC-WBC & 28.9 & 52.6 & 29.4 & 54.2 & 26.9 & 25.4 & $\mathrm{~S}$ \\
\hline Bio129-BC-WBC & 12.5 & 42.8 & 15.0 & 42.8 & 30.4 & 27.1 & $\mathrm{~S}$ \\
\hline Bio132-AC2-Blas & 23.3 & 27.1 & 38.7 & 27.1 & 22.5 & 36.8 & MR \\
\hline Bio138-AC2-Blas & 21.3 & 28.2 & 21.3 & 29.7 & 5.5 & 21.5 & MR \\
\hline Bio140-AC2-Blas & 28.5 & 32.4 & 28.4 & 32.4 & 3.0 & 15.5 & MR \\
\hline Bio148-Mamol-Dro & 28.9 & 25.7 & 31.7 & 36.3 & 8.0 & 16.5 & MR \\
\hline Bio154-Mamol-Dro & 41.1 & 29.1 & 18.5 & 29.7 & 17.3 & 17.0 & MR \\
\hline Bio155-Mamol-Dro & 13.8 & 48.2 & 25.3 & 48.2 & 14.5 & 28.8 & MR \\
\hline Bio157-Mamol-Dro & 30.7 & 32.1 & 30.7 & 32.1 & 17.0 & 33.6 & $\mathrm{~S}$ \\
\hline Bio159-Mamol-Dro & 18.8 & 39.4 & 21.2 & 47.5 & 20.0 & 19.8 & MR \\
\hline Bio 153-Mamol-Dro & 23.6 & 37.7 & 23.6 & 55.1 & 13.2 & 12.5 & MR \\
\hline Ciherang & 26.7 & 38.5 & 26.7 & 38.6 & 23.2 & 23.6 & $\mathrm{~S}$ \\
\hline INPARI 1 & 14.4 & 42.0 & 14.4 & 42.0 & 19.1 & 22.6 & $\mathrm{R}$ \\
\hline Pelita & 38.0 & 38.0 & 40.0 & 38.0 & 37.6 & 55.3 & $\mathrm{~S}$ \\
\hline Utri Rajapan & 14.0 & 13.8 & 20.0 & 14.9 & 15.7 & 18.3 & $\mathrm{R}$ \\
\hline Utri Merah & 14.0 & 15.1 & 14.2 & 13.3 & 10.0 & 17.9 & $\mathrm{R}$ \\
\hline
\end{tabular}

$\mathrm{R}$, resisten; MR, moderat resisten; $\mathrm{S}$, suseptibel. 


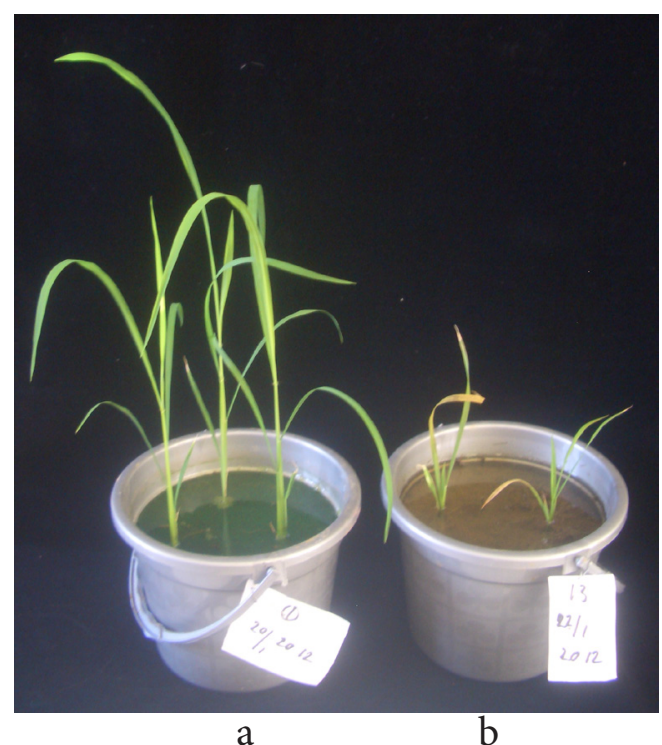

Gambar 1 Padi varietas Ciherang. a, Tanaman tidak diinokulasi virus tungro; $b$, Tanaman diinokulasi virus tungro isolat Bali.

\section{PEMBAHASAN}

Kejadian dan keparahan penyakit tungro merupakan hasil interaksi antara beberapa faktor, di antaranya isolat/galur virus, varietas padi, dan kondisi lingkungan di pertanaman termasuk keberadaan serangga vektor. Virulensi isolat/galur virus tungro dari beberapa daerah endemis penyakit tungro di Indonesia telah dilaporkan. Berdasarkan uji patogenisitas pada beberapa varietas padi dilaporkan bahwa isolat Subang dan Bali termasuk galur yang kuat sedangkan isolat Bogor adalah galur lemah (Widiarta et al. 2004). Galur-galur padi berbeda yang diinokulasi dengan isolat/galur virus tungro yang berasal dari daerah yang berbeda dapat menghasilkan respons yang sama atau berbeda. Suatu varietas padi dapat memberikan respons ketahanan yang sama terhadap infeksi galur virus tungro tertentu walaupun memiliki latar belakang gen ketahanan yang berbeda (Widiarta et al. 2004). Oleh karena itu, tidak semua varietas tahan dapat digunakan untuk mengendalikan penyakit tungro di semua daerah endemis, namun harus disesuaikan dengan variasi virulensi isolat antardaerah.

Penanaman varietas padi spesifik lokasi di suatu wilayah perlu diupayakan karena ada indikasi terjadinya perubahan tingkat patogenisitas virus yang ditunjukkan dengan suatu varietas yang sebelumnya tahan menjadi tidak tahan (Janzac et al. 2009; Suprihanto et al. 2013; Praptana dan Muliadi 2013). Pembentukan varietas tahan tungro yang bersifat durable resistance dengan pendekatan gene pyramiding menjadi salah satu pilihan untuk mengatasi perubahan keragaman genetik virus tungro (Azzam dan Chancellor 2002). Berdasarkan respons terhadap 3 isolat virus tungro yang berbeda, Galur Bio5-ACBlas/BLB, Bio62-AC-Blas/BLB-03, dan Bio111-BC-Pir7 dapat digunakan sebagai materi tetua dalam perakitan varietas tahan yang sesuai untuk semua galur virus tungro. Salah satu hambatan dalam penggunaan varietas tahan adalah durabilitas ketahanan yang menurun akibat tekanan seleksi populasi dan variasi virulensi patogen (Fabre et al. 2012). Durabilitas ketahanan varietas menjadi perhatian penting dalam pengendalian penyakit sehingga pemilihan tetua sebagai sumber dan kombinasi gen ketahanan berdasarkan kesesuaian interaksi patogen dengan ketahanan varietas sangat diperlukan dalam strategi perakitan varietas tahan (Palloix et al. 2009; Zhang et al. 2009 ).

Suatu varietas tahan yang dapat digunakan mengendalikan virus tungro di suatu daerah endemis harus memiliki beberapa sifat, yaitu tahan terhadap vektor serangga, tahan terhadap RTSV dengan batas insidensi penyakit $\leq 20 \%$, toleran terhadap RTBV dengan tingkat infeksi tinggi dan skor tingkat keparahan penyakit rendah, dan tahan terhadap kedua virus tersebut dengan batas insidensi penyakit $\leq$ 20\% (Azzam et al. 2000).

\section{DAFTAR PUSTAKA}

Azzam O, Chancellor TCB. 2002. The biology, epidemiology and management of rice tungro disease in Asia. Plant Dis. 86(2):88-100. DOI: http://dx.doi. org/10.1094/PDIS.2002.86.2.88.

Chancellor TCB, Cook AG, Heong KL. 1999. The epidemiology and management of rice 
tungro virus disease. NRI Final Technical Report. Los Banos(PH): IRRI.

Fabre F, Rousseau E, Mailleret L, Moury B. 2012. Durable strategies to deploy plant resistance in agricultural landscapes New Phytol. 193(4):1064-1075. DOI: http://dx.doi.org/10.1111/j.14698137.2011.04019.x.

Hull R, Harper G, Lockhart B. 2000. Viral sequences integrated into plant genomes. Trends Plant Sci. 5:362-365. DOI: http:// dx.doi.org/10.1016/S1360-1385(00)0172 3-4.

IRRI. 1996. Standard Evaluasi System for Rice. Los Banos(PH): IRRI.

Janzac B, Fabre F, Palloix A, Moury B. 2009. Constraints on evolution of virus avirulence factors predict the durability of corresponding plant resistances. Mol Plant Pathol. 10(5):599-610. DOI: http://dx.doi. org/10.1111/j.1364-3703.2009.00554.x.

Neeraja, Krishnaveni D, Saivishnupriya, Prasad V, Muralidhara K. 2010. Molecular mapping of resistance to tungro virus in rice cultivars Vikramarya and Utri Rajapan. Rice Gen Newsletter. 23:80-83.

Palloix A, Ayme V, Moury B. 2009. Durability of plant major resistance genes to pathogens depends on the genetic background, experimental evidence and consequences for breeding strategies. New Phytol. 183(1):190-199. DOI: http://dx.doi.org/ 10.1111/j.1469-8137.2009.02827.x.

Praptana H, Muliadi A. 2013. Durabilitas ketahanan varietas padi terhadap penyakit tungro. IPTEK Tanaman Pangan. 8(1):1-7. Suprihanto, Nurhayati E, Harjosudarmo J. 2013. Virulensi isolate Rice tungro virus dari beberapa daerah endemis tungro di Indonesia. J Fitopatol Indones. 9(1):2937. DOI: http://dx.doi.org/10.14692/ jif.9.1.129.

Widiarta IN, Burhanuddin A, Daradjat AA, Hasanuddin A. 2004. Status dan program penelitian pengendalian terpadu penyakit tungro. Di dalam: Prosiding Seminar Nasional Status Program Penelitian Tungro Mendukung Keberlanjutan Produksi Padi Nasional; 2004 Sep 7-8; Makassar (ID): Puslitbangtan, Badan Litbang Pertanian. hlm 61-89.

Zhang H, Li G, Li W, Song F. 2009. Transgenic strategies for improving rice disease resistance. African J Biotech. 8(9):17501757. 